\title{
INTELLIGENT TRANSPORT AS A KEY COMPONENT OF IMPLEMENTATION THE SUSTAINABLE DEVELOPMENT CONCEPT IN SMART CITIES
}

\begin{abstract}
European societies today face many sustainability challenges including but not limited to youth unemployment, aging populations, climate change, pollution, sustainable energy and migration. These problems are especially evident in cities. The objectives of smart development and integrated planning in European cities have been presented in the Europe 2020 strategy. It assumes restoration of European cities through stimulating innovation. In the socio-economic dimension, this means supporting the development of intelligent cities, often referred to as Smart Cities. According to the Smart City definition it is a city with the ability to adapt to the changing socio-economic conditions. This feature is extremely important in times of constant change. Progressing urbanization, globalization, technology transfer to everyday life and dwindling natural capital are the reasons why urban development is increasingly dependent on such factors as advanced technologies or territorial capital, understood as the available material and immaterial resources that determine the functioning of a given area. One of the Smart City components is intelligent transport. Improving mobility, ensuring accessibility and decreasing traffic congestion are some of the greatest challenges facing smart cities today. To respond to these challenges many city planners are glancing at smart transport solutions to reduce congestion as well as to optimize the use of city public transport. The aim of this article is to identify the challenges faced by European cities nowadays, present transport as a component of the Smart City and show its role in implementing the Smart City concept. The author presents European actions in terms of city mobility and recognizes their role in attaining the $11^{\text {th }}$ SDG. Particular attention is paid to cities of the new Member States. Some examples of activities undertaken and tools used by authorities of European cities will be cited
\end{abstract}


as examples of good practices. An analysis of the conditions for the transferability of such a solution will be included in the article.

Keywords: Smart City, intelligent transport, sustainable development, urban mobility

\section{Introduction}

The $21^{\text {st }}$ century is characterized by further, continuous development of cities and the deepening process of urbanization. Migrations to urban centres are progressing on all continents, which will lead to the situation that nearly three-quarters of the world's population will be living in cities towards the end of the century. Europe is one of the most urbanized continents. At the present time almost $70 \%$ of the population of the European Union (EU) lives in urban areas and the trends in this respect are growing. It is anticipated that $80 \%$ of the population will have lived in European cities by 2020 (UE, 2011, p. 9). Furthermore, research shows that cities are the driving force of the European economy and they are of essential significance for its proper functioning. It is sufficient to note that approx. $85 \%$ of the EU's GDP is generated in urban areas (Communication from the Commission, 2013, p. 2). Therefore, it should be expected that the development of cities will determine the future development of the EU in economic, social and territorial terms.

It should also be remembered that cities are centres of change based on innovation, the spirit of entrepreneurship and economic growth (Communication from the Commission, 2010, p. 4). The issue of sustainability is of particular significance in cities that are more exposed to social exclusion, environmental degradation, existence of wasteland and uncontrolled sprawl of cities. Economic growth is described as sustainable, when it is accompanied by measures aimed at reducing poverty and social exclusion, and counteracting environmental problems.

Smart cities are a concept that involves interaction of residents, local authorities, entrepreneurs and other institutions at all stages of their functioning. The main objective of this idea is to strive for using the available space and resources in the most efficient way, with the support of the technology and direct activity of residents. Hence, it is said that a measure of the city's smartness is the local economy structure, the level of solutions supporting mobility and resource management, including environmental resources. And the key to success in implementing the idea are conscious and active residents.

Transport plays a key role in the implementation of this idea, hence, the aim of this article is to identify the challenges faced by European cities nowadays, present transport area as a component of the Smart City and show its role in the implementation of the Smart City concept. The author presents European actions in terms of city mobility and recognizes their role in the implementation of the $11^{\text {th }}$ SDG. Particular attention is paid to cities of the new Member States. Some examples of activities undertaken and tools used by authorities of European cities will be cited as examples of good practices. This is aimed at showing the directions of transport development in the city and its impact on the implementation of the smart city concept in practice. 


\section{Sustainable development of cities in the 2030 Agenda}

The city and its features have been formed in the process of historical development. The functioning of a city is governed by its own rules and is characterized by certain regularities. It is a product of the civilization, a specific form of agglomeration of people, conditioned by the historical process of deepening of the social distribution of labour (Schlappa, Neil, 2013, p. 32). It is a dynamic organism undergoing constant changes, both in quantitative and qualitative terms.

In the early $19^{\text {th }}$ nineteenth century, cities around the world were inhabited less than $2.5 \%$ of the population, while it was as much as approx. $30 \%$ in 1950. In the early $21^{\text {st }}$ century, the urban population grew up to $50 \%$. The forecasts show further growth of this percentage. By 2050, two-thirds of humanity will have been city dwellers, and there will have been more than 40 mega-cities populated by at least 10 million (United Nations, 2015b, p. 1). Modern cities undergo constant transformations, change their structures, experience stages of intensive development or enter a declining phase.

Urbanization is one of the most characteristic socio-economic changes on a global scale of a lasting nature and having a significant impact on all areas of the life of people. The process of urbanization, or "urban transition", describes a shift in a population from one that is dispersed across small rural settlements in which agriculture is the dominant economic activity towards one where the population is concentrated in larger, dense urban settlements characterized by industrial and service activities (Montgomery, Eds., 2004).

Historically, the urban transition has been linked closely to economic development. In Europe and Northern America, rapid urbanization over the late-nineteenth and twentieth centuries was observed to accompany the industrial revolution and rapid economic growth. A similar, although generally weaker, association between urbanization, industrialization and economic development has been observed more recently in many parts of developing regions (Grübler, Fisk, Eds., 2013). The urban transition and economic growth have been linked in part because economic development fuels urbanization. People are drawn to cities that offer varied opportunities for education and employment, particularly in the industry and services sectors.

Urbanization, in turn, generally has had a positive impact on economic development and poverty reduction. However, it is of a heterogeneous nature and has many dimensions: economic, demographic, spatial, social, legal or environmental (Szymańska, Biegańska, 2011, p. 14). Typically, this is reflected in the fact that urbanization means both processes of concentration and deconcentration, which occur at the same time in the same space. Many scientists studying this issue claim that contemporary urbanization is manifested in an advanced form of both suburbanization and urban sprawl with the large cities sprawling and vast suburbs spreading, and entering deeper and deeper into typical rural areas through the expansion of the residential infrastructure and services. The development of the city is a process of continuous positive changes taking place in the urban economy. A condition for such development is the mutual interdependence of the city subsystems, i.e. economic, social and environmental (Markowski, 2008, p. 14). 
Scientists have no doubts that cities are important drivers of the economy, being places of meetings, creativity and innovation, and centres of services provided to the surrounding areas. Due to the density of population, cities have an enormous potential in terms of energy saving and transformations towards a low-emission economy. Nevertheless, cities are also places of concentration of such problems as unemployment, exclusion, poverty or environmental degradation. Therefore, cities are of essential importance for the successful implementation of the 2030 Agenda.

Paragraph 34 of the Agenda recognizes that both sustainable urban development and management are crucial to the quality of life of people (United Nations, 2015a). The document emphasizes the necessity to reduce the negative impacts of urban activities and the need to undertake work to minimize the impact of cities on the global climate system. One of the 17 Sustainable Development Goals (SDGs) - Goal 11: 'Make cities and human settlements inclusive, safe, resilient and sustainable' refers to the management of urbanization processes. The seven following tasks serve for attaining this goal (Sustainable Development Knowledge Platform, 2015):

1. By 2030, ensure access for all to adequate, safe and affordable housing and basic services and upgrade slums.

2. By 2030, provide access to safe, affordable, accessible and sustainable transport systems for all, improving road safety, notably by expanding public transport.

3. By 2030, enhance inclusive and sustainable urbanization and capacity for participatory, integrated and sustainable human settlement planning and management in all countries.

4. Strengthen efforts to protect and safeguard the world's cultural and natural heritage.

5. By 2030, significantly reduce the number of deaths and the number of people affected and substantially decrease the direct economic losses relative to global gross domestic product caused by disasters.

6. By 2030, reduce the adverse per capita environmental impact of cities, including by paying special attention to air quality and municipal and other waste management.

7. By 2030, provide universal access to safe, inclusive and accessible, green and public spaces.

The accomplishment of the foregoing tasks is essential for creating safe, inclusive and sustainable cities. This is extremely important in light of the UN forecasts which indicate that the world population will have doubled by 2030 , while the size of urban areas will have increased three times (United Nations, 2016).

While there are numerous definitions of sustainable development, many start with the definition provided in the 1987 Brundtland Report: "Development that meets the needs of the present without compromising the ability of future generations to meet their own needs." (WCED, 1987). The goals for sustainable cities are grounded on a similar understanding - urban development which strives to meet the essential needs of all, without overstepping the limitations of the natural environment. A sustainable city has to achieve a dynamic balance among economic, environmental and socio-cultural development goals, framed 
within a local governance system characterized by deep citizen involvement and inclusiveness (McCarney, 2006). A core component of the agenda of sustainable cities is a sustainable infrastructure - an interconnected physical and organizational structure, a set of services and a system that supports the daily functioning of the society and its economy. Sustainable infrastructure is that which is designed, developed, maintained, reused, and operated in a way that ensures minimal strain on resources, the environment and the economy. It contributes to enhanced public health and welfare, social equity, and diversity (United Nations, 2015a).

\section{Smart City concept - a literature review}

The complexity of social, economic, spatial and environmental problems typical for cities and urban areas and the dynamics of these changes in these areas force urban communities to seek more efficient and effective methods for managing urban affairs. Many city development models have been produced in line with the idea of sustainable development, technological revolution and forming of a knowledge-based economy. One of these is the Smart City model in which an important role is played by investments in various areas of the city's functioning which is aimed at improving the quality of life of residents and ensuring effective management of resources. These investments are based mainly on the use of advanced technologies and innovative solutions of the Information and Communication Technologies (ICT) sector. Table 1 shows a review of concepts related to the development of contemporary cities.

Table 1. Review of concepts related to the development of contemporary cities

\begin{tabular}{|l|l|}
\hline \multicolumn{1}{|c|}{ Concept } & \multicolumn{1}{|c|}{ Description of areas } \\
\hline $\begin{array}{l}\text { Information City, Virtual City, Cyber City, } \\
\text { Wireless City, Mobile City, Technocity, Digital } \\
\text { City, Intelligent City, Connected City, Wired City }\end{array}$ & IT/ICT, technical infrastructure, social networks \\
\hline $\begin{array}{l}\text { Eco-City, Green City, Slow City, Techno- } \\
\text { Ecological City }\end{array}$ & $\begin{array}{l}\text { Environmental protection, sustainable } \\
\text { consumption, renewable energy sources, smart } \\
\text { grid }\end{array}$ \\
\hline $\begin{array}{l}\text { Knowledge-Based City, Creative City, Clever } \\
\text { City }\end{array}$ & $\begin{array}{l}\text { Intellectual capital, education, social and human } \\
\text { capital }\end{array}$ \\
\hline $\begin{array}{l}\text { Interactive City, Cooperative City, Responsive } \\
\text { City, } \\
\text { Idea-City }\end{array}$ & $\begin{array}{l}\text { Social and human capital, joint creation } \\
\text { of values, participation of residents } \\
\text { in management processes }\end{array}$ \\
\hline Just City & $\begin{array}{l}\text { Social and human capital, democracy, human } \\
\text { rights }\end{array}$ \\
\hline Happy City, Dream City, Liveable City, Slow City & $\begin{array}{l}\text { Social and human capital, quality of life, } \\
\text { sustainable consumption, revitalization }\end{array}$ \\
\hline $\begin{array}{l}\text { Sustainable City, Smart City, Smart-Networked } \\
\text { City }\end{array}$ & $\begin{array}{l}\text { Convergence of smart solutions in many areas: } \\
\text { ICT, power grids, transport infrastructure, } \\
\text { security, mobility, management, combined with } \\
\text { the activity of residents }\end{array}$ \\
\hline
\end{tabular}

Source: (Pieriegud, 2018, p. 20) 
In the literature on the subject, the term 'Smart City' is often used interchangeably with such terms as: 'Intelligent City', 'Knowledge City', 'Sustainable City', 'Digital City' or 'Wired City'. This is due to the fact that the basic assumptions for all the above terms are to a large extent similar (Table 1), nonetheless, it is the term 'Smart City' that is the most popular and most frequently used notion (Nam, Pardo, 2011, p. 284). There is no single, generally accepted definition of an smart city. Depending on the expert's specialization and the purpose of creating such a definition, each of the experts engaged with smart cities focuses on different aspects of the city's 'intelligence'. This can be a system of management and energy saving, the use of smart transport systems or the degree of digitization of public administration or the specificity of jobs dominating in a given region.

In recent studies published over a period of five years, it is emphasized that the discussion on the Smart City should focus not only on the technological aspects and the technical infrastructure, but also, and perhaps primarily, on how to improve the dialogue between residents and authorities. A city is first of all a community of people, hence, social participation in the decisions concerning cities is a key factor towards their development.

Caragliu defines the 'Smart City' as a city in which "investments in human and social capital and traditional (transport) and modern (ICT) communication infrastructure fuel sustainable economic growth and a high quality of life, with a wise management of natural resources, through participatory governance" (Caragliu, Del Bo, Nijkamp, 2009, p. 67).

One of the most frequently cited scientific definitions describes a smart city as such "in which ICT are widely and equally used by business, administration, community and ordinary people" (Holland, 2008, p. 315).

The Shanghai Manual, a UN guide for sustainable urban development in the $21^{\text {st }}$ century, identifies smart cities as "using a combined (digital) infrastructure to improve economic and political efficiency and enable better social, cultural and urban development" (Shanghai Manual, 2010). A broad review of the Smart City definitions is included in the publication edited by Szelągowska (2017).

It follows from the various definitions of the concept that a smart city integrates selected infrastructure systems. It is a city that is able to optimize its resources, monitor the security level aspects, plan the maintenance activities. This in turn contributes to improving the quality of life in a given place. Specialists in the field of urban planning, civil servants, the academic world and investors argue that the implementation of the smart city idea contributes to the increase in the efficiency of public space management and positively affects the quality of life of residents (Albino, Berardi, Dangelico, 2015, pp. 10-13).

The literature on the subject lists six dimensions making up the concept of a smart city. The specific components are presented in Table 2. 
Table 2. Smart City components

\begin{tabular}{|c|c|c|}
\hline Smart City component & Description & $\begin{array}{l}\text { Related aspect } \\
\text { of urban life }\end{array}$ \\
\hline Smart Economy & $\begin{array}{l}\text { Cities should demonstrate high productivity, a climate } \\
\text { of innovation and flexibility of the labour market }\end{array}$ & Industry \\
\hline Smart Mobility & $\begin{array}{l}\text { Smart mobility means modern transport and logistic } \\
\text { systems using ICT to enhance their integrity with } \\
\text { the environment and enable people and goods } \\
\text { to move around in a safe, user and environment } \\
\text { friendly manner as well as in an efficient and cost- } \\
\text { effective way. }\end{array}$ & $\begin{array}{l}\text { Logistics } \\
\text { \& infrastructures }\end{array}$ \\
\hline Smart Environment & $\begin{array}{l}\text { A city optimizing energy consumption, inter alia, } \\
\text { through the use of renewable energy sources, carrying } \\
\text { out activities aimed at reducing emissions pollution } \\
\text { to the environment, and the resource management } \\
\text { is based on the principle of sustainable development }\end{array}$ & $\begin{array}{l}\text { Efficiency } \\
\text { \& sustainability }\end{array}$ \\
\hline Smart People & $\begin{array}{l}\text { The initiators of changes in cities should be residents } \\
\text { who, with the appropriate technical support, are } \\
\text { able to prevent excessive energy consumption, } \\
\text { environmental pollution and strive for improving } \\
\text { the quality of life; }\end{array}$ & Education \\
\hline Smart Living & $\begin{array}{l}\text { The city provides its residents with a friendly } \\
\text { environment by ensuring 'wide access to public } \\
\text { services, the technical and social infrastructure, } \\
\text { a high level of security and, thanks to the appropriate } \\
\text { cultural and entertainment offer, the care for } \\
\text { the environment and green areas; }\end{array}$ & Security \& quality \\
\hline Smart Governance & $\begin{array}{l}\text { Development in this aspect requires creation } \\
\text { of an appropriate city management system, } \\
\text { developing procedures requiring cooperation } \\
\text { of local authorities and other city users, and the use } \\
\text { of modern technologies in the functioning of the city. }\end{array}$ & e-democracy \\
\hline
\end{tabular}

Source: (EEA, 2010; Lombardi et al., 2012, p. 140)

In practice, all the mentioned contemporary smart city components are mutually integrated with each other, despite the fact that they concern various sectors and aspects of life. The smart city model in the original understanding, the so-called Smart City 1.0, assumed only wider use of modern technologies in cities, and the main initiator of activities were companies and representatives of the ICT sector. The next phase of smart city modelling, Smart City 2.0, assumed greater participation of decision makers and local authorities in the selection of the place of application of modern technologies. However, the most up-to-date and popular smart city concept - Smart City 3.0 - assumes active participation of city dwellers in creating and using intelligent solutions in all these areas in order to adjust them to the actual needs of residents (Cohen, 2015).

At the present time, many cities in Europe, as well as in the world, develop according to the Smart City model. At the beginning of 2013, there were approximately 143 ongoing or completed self-designated Smart City projects. Among these initiatives, North America had 35 projects; Europe, 47; Asia 50; South America 10; and the Middle East and Africa 10 (Lee, Hancock, Hu, 2014). The European 
Union has put in place Smart City actions in several cities, including in Barcelona, Amsterdam, Berlin, Manchester, Edinburgh, and Bath. In the United Kingdom, almost 15 years ago, Southampton claimed to be the country's first Smart City after the development of its multi-application smartcard for public transportation, recreation, and leisure-related transactions. Similarly, Tallinn has developed a large-scale digital skills training program, extensive e-government, and an award-winning smart ID card (Albino, Berardi, Dangelico, 2015, p. 15).

Since 2007, the TUWIEN team has worked on the issue of smart cities. The European Smart City Model has been developed in cooperation with different partners and in the run of distinct projects financed by private or public stakeholders and actors. Basically it provides an integrative approach to profile and benchmark European medium-sized cities. 90 European cities with a population of 0.3-1.0 million were included in the European Smart City ranking of 2015. Figure 1 shows the cities included in the 2015 ranking. There were 20 cities from the new Member States included in the ranking. The greatest number of them, as many as 9, came from Poland (Bydgoszcz, Gdańsk, Katowice, Kraków, Lublin, Łódź, Poznań, Szczecin and Wrocław), there were 2 cities Bulgaria (Plovdiv and Varna), (Cluj-Napoca and Timisoara), Lithuania (Kaunas and Vilnius) and the Czech Republic (Brno and Ostrava) and one city from Latvia (Riga), Estonia (Tallinn), Slovakia (Bratislava). The detailed methodology of the ranking can be found in the final report of the project implemented by the team from the Vienna University of Technology (Centre of Regional Science, 2007).

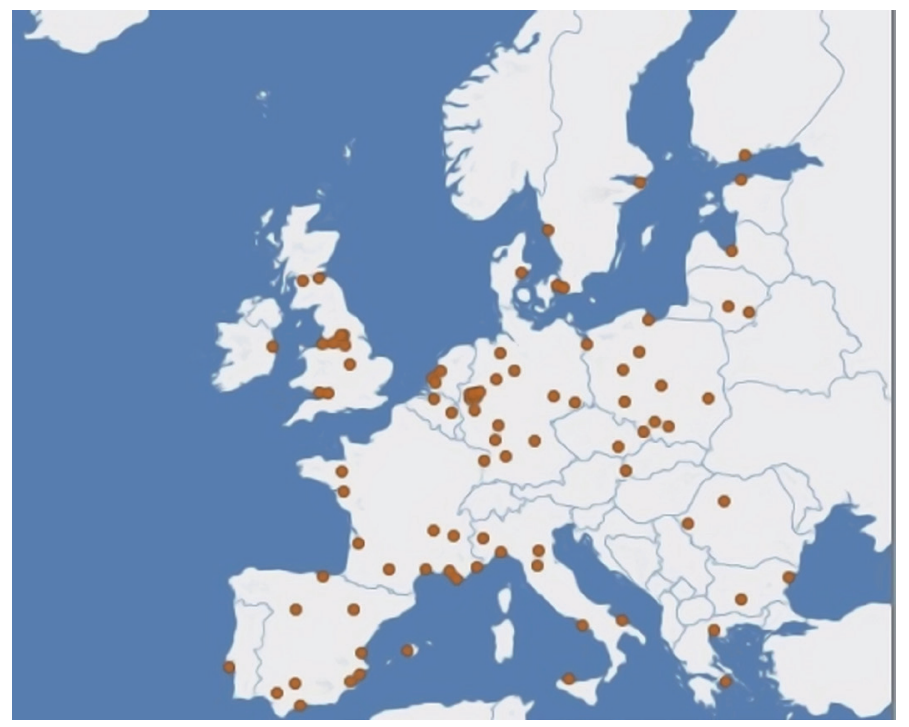

Figure 1. European medium-sized cities in Smart City ranking in 2015 Source: (Europeansmartcities 4.0, 2015)

In the quoted ranking, the comparative analysis of cities was based on the six previously mentioned distinctive components of a smart city with additionally defined indicators (see Table 3). 
Table 3. Indicators and parameters used to rank European Smart Cities

\begin{tabular}{|c|c|c|}
\hline Smart Economy & Smart Mobility & Smart Environment \\
\hline $\begin{array}{ll}\text { - } & \text { innovation } \\
\text { - } & \text { entrepreneurship } \\
- & \text { economic image } \\
& \text { and trademarks } \\
\text { - } & \text { labour market flexibility } \\
\text { - } & \text { international position }\end{array}$ & $\begin{array}{ll}- & \text { national and international } \\
& \text { transport availability } \\
- & \text { IT infrastructure availability } \\
- & \text { transport system } \\
& \text { sustainability level }\end{array}$ & $\begin{aligned}- & \text { condition of environment } \\
- & \text { air quality } \\
- & \text { level of social environmental } \\
& \text { awareness } \\
- & \text { sustainable management } \\
& \text { of resources }\end{aligned}$ \\
\hline Smart People & Smart Living & Smart Governance \\
\hline $\begin{aligned} \text { - } & \text { level of human capital } \\
& \text { qualifications } \\
\text { - } & \text { willingness of life long } \\
& \text { education } \\
\text { - } & \text { cultural diversity } \\
\text { - } & \text { tolerance }\end{aligned}$ & $\begin{aligned}- & \text { functioning cultural centres } \\
- & \text { access to health care } \\
- & \text { individual security } \\
& \text { of residents } \\
- & \text { quality of residential } \\
& \text { housing } \\
- & \text { functioning educational } \\
& \text { centres } \\
- & \text { tourist attractiveness } \\
- & \text { economic prosperity level }\end{aligned}$ & $\begin{aligned} \text { - } & \text { level of public participation } \\
& \text { in public life and decision- } \\
& \text { making processes } \\
- & \text { level of available public } \\
& \text { services } \\
- & \text { transparency } \\
& \text { of management }\end{aligned}$ \\
\hline
\end{tabular}

Source: (own elaboration based on: Europeansmartcities 4.0, 2015)

Figure 2 presents the characteristics of 12 selected Central and Eastern European cities in terms of the 6 Smart City components.
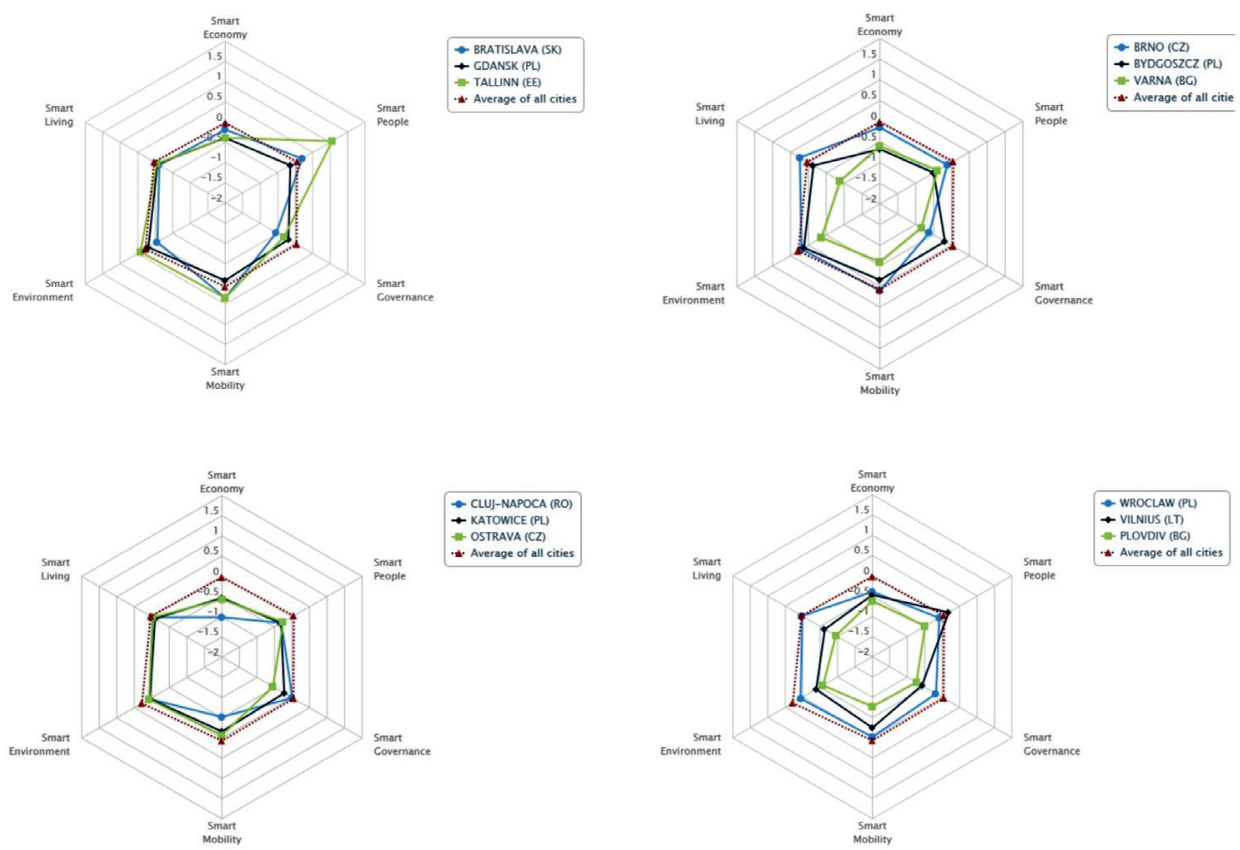

Figure 2. Characteristics of selected Central and Eastern European cities according to Smart City components

Source: (own elaboration based on: Europeansmartcities 4.0, 2015) 
As follows from the presented comparison of 12 Central and Eastern European cities there are significant differences between cities in terms of specific Smart components. Table 4 presents the characteristics of selected cities compared to the average values for the 90 ranked cities.

Table 4. Characteristics of Central and Eastern European cities in comparison to the average values for the 90 ranked European cities

\begin{tabular}{|l|c|c|c|c|c|c|c|}
\hline \multicolumn{1}{|c|}{ City } & $\begin{array}{c}\text { Smart } \\
\text { Economy }\end{array}$ & $\begin{array}{c}\text { Smart } \\
\text { Mobility }\end{array}$ & $\begin{array}{c}\text { Smart } \\
\text { Environ- } \\
\text { ment }\end{array}$ & $\begin{array}{c}\text { Smart } \\
\text { People }\end{array}$ & $\begin{array}{c}\text { Smart } \\
\text { Living }\end{array}$ & $\begin{array}{c}\text { Smart } \\
\text { Govern- } \\
\text { ance }\end{array}$ & Average \\
\hline Bydgoszcz (PL) & -0.676 & -0.161 & $\mathbf{0 . 1 2 4}$ & -0.497 & -0.144 & -0.181 & -0.256 \\
\hline Brno (SK) & -0.152 & 0.101 & $\mathbf{0 . 1 9 2}$ & -0.115 & $\mathbf{0 . 2 5 8}$ & -0.617 & -0.059 \\
\hline Varna (BL) & -0.604 & -0.595 & -0.369 & -0.388 & $\mathbf{0 . 8 8 9}$ & -0.842 & -0.615 \\
\hline Katowice(PL) & -0.531 & -0.165 & $\mathbf{0 . 0 5 8}$ & -0.314 & -0.053 & -0.220 & -0.211 \\
\hline Ostrava (CZ) & -0.570 & -0.072 & $\mathbf{0 . 0 8 2}$ & -0.253 & -0.031 & -0.542 & -0.231 \\
\hline $\begin{array}{l}\text { Cluj-Napoca } \\
\text { (RO) }\end{array}$ & -1.009 & -0.522 & $\mathbf{0 . 0 6 9}$ & -0.305 & -0.024 & $\mathbf{0 . 0 0 9}$ & -0.297 \\
\hline Bratislava (CZ) & -0.197 & $\mathbf{0 . 3 4 6}$ & -0.062 & 0.198 & -0.118 & -0.535 & -0.060 \\
\hline Gdańsk (PL) & -0.390 & -0.085 & $\mathbf{0 . 1 9 4}$ & -0.139 & -0.063 & -0.194 & -0.113 \\
\hline Tallinn (EE) & -0.389 & $\mathbf{0 . 3 4 8}$ & $\mathbf{0 . 4 2 0}$ & $\mathbf{1 . 0 5 5}$ & -0.045 & -0.321 & $\mathbf{0 . 1 7 8}$ \\
\hline Wroclaw (PL) & -0.395 & -0.020 & $\mathbf{0 . 0 6 1}$ & -0.082 & $\mathbf{0 . 0 1 4}$ & -0.176 & -0.100 \\
\hline Vilnius (LT) & -0.473 & -0.247 & -0.388 & $\mathbf{0 . 1 8 7}$ & -0.637 & -0.581 & -0.357 \\
\hline Plovdiv (BL) & -0.623 & -0.770 & -0.585 & -0.489 & -0.952 & -0.738 & -0.693 \\
\hline
\end{tabular}

Source: (own elaboration based on: Europeansmartcities 4.0, 2015)

Unfortunately, as can be seen from the ranking, medium-sized Central and Eastern European cities negatively depart from the average for the cities included in the European ranking in terms of the Smart City components. It is practically in Tallinn only that the average for all components is above the average, namely 0.178 . The best results are achieved for the Smart Environment component, as the result is worse than the European average only in 3 out of 12 cities with the average for the 12 cities being -0.017 . The poorest result - the average for the cities -0.5 was noted for the Smart Economy component. Virtually none of the surveyed cities has exceeded the European average. The poorest results were noted in Cluj-Napoca (RO) -1.009, Varna (BL) -0.604 and Bydgoszcz (PL) -0.676. In respect of the Smart Mobility component, it was only two of the twelve cities that achieved a result above the European average. These were Tallinn (EE) and Bratislava (SK) with the result of 0.348 and 0.346 , respectively. The summary shows that it is required to undertake additional actions in Central and Eastern European cities to support the implementation of the Smart City concept.

\section{Smart mobility as a Smart City component}

According to the assessment conducted in the foregoing section of the article, the Smart Mobility component requires additional actions. In recent years, the issues 
of transport management in cities have been the subject of many documents issued by the European Commission. The most important of these include: (1) Green Paper - Towards a new urban mobility culture (2007); (2) Plan for urban mobility (2009); (3) White Paper of Transport (2011); (4) Package for urban mobility (2013).

The new approach to urban mobility means optimising the use of the various means of transport and the creation of co-modality between different modes of public transport (train, tram, underground, bus, taxi) and different types of individual transport (car, motorcycle, bicycle, walking on foot). It also covers the implementation of common goals in terms of economic well-being, management of the demand for transport to ensure mobility, an appropriate living and environmental protection standards. Transport is included among the key areas as far a creating the quality of life in urban areas is concerned. When analyzing the available forecasts by 2030 , it is expected that the demand for passenger transport ( $\mathrm{pkm}$ ) will increase by $42 \%$ compared to 2000, and the road transport share will reach $85 \%$, with the passenger car traffic growing up to $75 \%$. These estimations give grounds to believe that the living conditions in cities will deteriorate, and the costs related to the waste of time will be much higher than today (Pawłowska, 2013, p. 263).

The basic challenges of the modern transport policy include reducing the share of individual motorisation in the transport structure. This issue is particularly important in urban areas, where congestion generates significant economic costs and entails specific risks for the natural environment and air quality, negatively affects the health of residents and as a result. Bannister (2008) defines four basic thematic areas which are the starting point for activities related to sustainable urban mobility. The areas deserving attention include the postulate of optimized utilization of the existing, available and proven technologies which create new conditions for the development of transport in cities owing to the process-based (e.g. urban transport market organisation favourable to intermodality) and product-based (electronic payments, electronic tickets and integrated tariff-ticket systems) innovations. It is necessary to include the changing needs of transport users in the planning processes of transport systems.

An important step towards the integration of the means transport is the concept of Mobility-as-a-Service or Transport as a Service (MaaS) belonging to the latest instruments in the area of creation of transport services and shaping the transport preferences and behaviour. MaaS radically changes the way in which the transport services market operates, and in the literature on the subject it is often presented as one of the most revolutionary trends in the transport sector. In MaaS systems, users and their needs are a key variable for planning and operation of the transport sector. The effect of implementing the MaaS model is a personalized, comprehensive offer of transport services tailored to the declared needs of its users (Zawieska, 2018, p. 32).

The modern MaaS solutions usually take the form of digital platforms and applications similar to travel planners. However, their application is more extensive. An important feature of such solutions is also the possibility of making reservations and payment for the selected transport service integrated with the application, regardless of the preferred means of transport - public or private. The information in real time on the traffic overload on specific sections and nodes of the transport 
infrastructure, as well as on the occurrence of failures and breaks in its operation is of key importance. Therefore, MaaS should be understood as a model for the provision of a transport service integrating many separate modes of transport, designed to facilitate the intermodal and balanced movement and which is the most effective from the user's point of view.

The basis features of the MaaS model can include the following goals (Evangelatos, 2016):

1. Seamless and effective flow of data, goods and people on both short and long distances.

2. Globally scalable door-to-door transport services available without possessing one's own car.

3. The level of quality and comfort of transport services is higher than in the case of individual trips using private passenger cars.

4. The system is open for information and interaction with solutions in the field of intelligent transport systems (ITS).

The efficiency the MaaS model is influenced by many legal, organizational and technological factors as well as the interaction of various stakeholders. The integration of various means of transport has been the preferred process in the transport policy for many years. However, due to the various constraints, this process has involved mainly public transport in cities. MaaS transfers the integration and multimodality in transport to a higher level. MaaS solutions integrate the transport services provided by many both public and private operators into one product. These entities often represent very different interest groups (e.g. taxis vs. public transport) and the basic challenge is to obtain the consent of all stakeholders to act as one superior transport service.

The MaaS model is a digital platform largely based on modern ICT technologies (Eckhardt et al., 2017). However, this involves many technological challenges. The most important of these is the potential lack of compatibility between the IT systems of individual operators included in the model. Data synchronization is a fundamental technological challenge for the project integrating data from so many sources and systems.

The basic activities at the strategic level, required for wider implementation of MaaS include legislative changes. The MaaS concept, like many innovative solutions in this field, is not adequately addressed in the applicable laws and regulations. The basic aspects requiring regulatory action include, but are not limited to, market control and quality control of the services provided, protection of consumer rights for the MaaS system users, ensuring responsibility for the safety of passengers, and on a local scale, providing the possibility of travelling with one ticket (application) in many different means of public and private transport. The availability of the service should also be considered. In the contemporary society, especially in poorer regions, there are many social groups suffering from digital exclusion, i.e. not using and not having access to ICT. This should be kept in mind when introducing the MaaS service.

MaaS is undoubtedly a concept favouring sustainable development and improving the environmental relations of the transport sector. Unfortunately, it is at an early stage of development and despite the fact that in many places components of this 
service can be seen, it is only few cities, such as Helsinki, Vienna, Goteborg that can boast of a higher level of advancement in this type of service (Deloitte, 2017). Undoubtedly, this is a future tool for implementing the Smart City concept in European cities.

\section{Conclusions}

Tracking the last twenty years of development reveals a global transformation that positions cities at the core of the development agenda. Urbanization is indeed one of the most significant trends of the past and present centuries, providing the foundation and momentum for a global change. The shift towards an increasingly urbanized world constitutes a transformative force which can be harnessed for a more sustainable development trajectory, with cities taking the lead to address many of the global challenges of the $21^{\text {st }}$ century, including poverty, inequality, unemployment, environmental degradation, and climate change. Cities have become a positive and potent force for addressing sustainable economic growth, development and prosperity, and for driving innovation, consumption and investment in both developed and developing countries.

Smart Cities have become a landmark in urban planning. They are the result of knowledge-intensive and creative strategies aiming at enhancing the socio-economic, ecological, logistic and competitive performance of cities. Such Smart Cities are based on a promising mix of human capital (e.g. skilled labor force), infrastructural capital (e.g. high-tech communication facilities), social capital (e.g. intense and open network linkages) and entrepreneurial capital (e.g. creative and risk-taking business activities). Smart Cities are supposed to be supported by appropriate and trustworthy governance structures and by open-minded, creative people, who through a joint effort are able to increase local productivity.

The smart city concept can be considered as an ambitious idea, the implementation of which requires finding new solutions in various areas. If it is intended to lead to an evolution of the existing cities to the level of smart cities, first of all, it is necessary to prepare new solutions in the infrastructure sectors, including the transport sector. New solutions in the area of mobility are closely related to the multidimensional Smart City concept. The introduction of Mobility-as-a-Service in a wider scope will require many significant changes. These will include, without being limited to, providing access to the state-of-the-art power and ICT infrastructure, as well as preparing and implementing new models of cooperation for many various stakeholders. This service also offers a number of benefits for a potential user. The expected effect is supposed to be a significant reduction in the need for owning a passenger car, which is nowadays desirable for comfortable and flexible journeys. In consequence a change in the transport branch structure of the city is supposed to occur.

The effect of all these activities will be better life of city residents and sustainable urban development, supporting the attainment of the $11^{\text {th }}$ goal of the 2030 Agenda. 


\section{References}

Albino, V., Berardi, U., Dangelico, R.M. (2015), Smart Cities: Definitions, Dimensions, Performance, and Initiatives, Journal of Urban Technology, 22:1., pp. 3-21.

Banister, D. (2008), The sustainable mobility paradigm, Transport Policy, 2, pp. 73-80.

Caragliu, A., Del Bo, C., Nijkamp, P. (2009), Smart Cities in Europe, Series research memoranda 0048, VU University Amsterdam, Faculty of Economics, Business Administration and Econometrics. Available from http://ideas.repec.org/vua/wpaper/2009-48.html [Accessed 12 October 2018].

Centre of Regional Science (2007), Smart cities Ranking of European medium-sized cities, Centre of Regional Science, Vienna UT.

Cohen, B. (2015), The 3 Generations of Smart Cites. Available from https://www.fastcoexist. com/3047795/the-3-generations-of-smart-cities [Accessed 15 October 2018].

Communication from the Commission (2010), Communication from the Commission Europe 2020, A strategy for smart, sustainable and inclusive growth, COM(2010) 2020 final, Brussels, 3.3.2010.

Communication from the Commission (2013), Communication from the Commission to the European Parliament, the Council, the European Economic and Social Committee and the Committee of the Regions, Together towards competitive and resource-efficient urban mobility, $\operatorname{COM(2013)~} 913$ final, Brussels, 17.12.2013.

Deloitte (2017), Deloitte Review. The rise of mobility as a service, Deloitte Development LLC.

Eckhardt, J., Aapaoja, A., Nykänen, L., Sochor, J., Karlsson, M., König, D. (2017), Deliverable 2: European MaaS Roadmap 2025, MAASiFiE, CEDR, Brussels.

EEA (2010), The European Environment State and Outlook 2010 - Land Use. Available from http:// www.eea.europa.eu/soer/europe/land-use [Accessed 30 September 2018].

Europeansmartcities 4.0 (2015). Available from http://www.smart-cities.eu/index.php?cid=7 \&ver $=4$ [Accessed 12 October 2018].

Evangelatos, S. (2016), Mobility as a Service (MaaS) Concept and Landscape, EuTravel, Barcelona.

Grübler, A., Fisk, D. (Eds.) (2013), Energizing Sustainable Cities: Assessing Urban Energy, Abingdon, United Kingdom, Routledge.

Holland, R.G. (2008), Will the Real Smart City Please Stand Up, City, 3, pp. 303-320.

Lee, J.H., Hancock, M.G., Hu, M-Ch. (2014), Towards an effective framework for building smart cities: Lessons from Seoul and San Francisco, Technological Forecasting and Social Change, 89, pp. 80-99.

Lombardi P., Giordano S., Farouh H., Yousef W. (2012), Modelling the Smart City Performance, Innovation: The European Journal of Social Science Research, 2, pp. 137-149.

Markowski ,T. (2008), Teoretyczne podstawy rozwoju lokalnego i regionalnego, In: Strzelecki, Z. (Ed.), Gospodarka regionalna i lokalna, PWN, Warszawa, pp. 13-28.

McCarney, P. (2006), Our future: sustainable cities - Turning ideas into action, World Urban Forum III Background Paper, UN-Habitat.

Montgomery, R.M. (Eds.) (2004), Cities Transformed: Demographic Change and its Implications in the Developing World, London, Earthscan.

Nam, T., Pardo ,T.A. (2011), Conceptualizing Smart City With Dimensions of Technology, People, and Institution, Proceedings of 12th Annual International Conference on Digital Government Research, Nowy Jork, pp. 282-290.

Pawłowska, B. (2013), Zrównoważony rozwój transportu na tle wspótczesnych problemów społeczno-gospodarczych, Wyd. Uniwersytetu Gdańskiego, Gdańsk.

Pieriegud, J. (2018), Aglomeracje przyszłości: koncepcje i wyzwania w erze cyfrowej. In: Mobilność w aglomeracjach przyszłości, Gajewski, J., Paprocki, W., Pieriegud, J. (Eds.), Centrum Myśli Strategicznych, Sopot. 
Schlappa H., Neil W. (2013), Cities of Tomorrow, Action Today: From Crisis to Choice Re-Imagining the Future in Shrinking Cities, URBACT, http://urbact.eu/fileadmin/general_library/19765 Urbact_WS1_SHRINKING_low_FINAL.pdf [Accessed 10 October 2018].

Shanghai Manual (2010), A Guide for Sustainable Urban Development in the 21st Century, United Nations Bureau International des Expositions, Szanghaj.

Sustainable Development Knowledge Platform (2015). Available from https://sustainabledevelopment.un.org/sdg11 [Accessed 15 September 2018].

Szelągowska, A. (Ed.) (2017), Inwestycje w zrównoważonym rozwoju miast, CeDeWu, Warszawa.

Szymańska, D., Biegańska, J. (2011), Fenomen urbanizacji i procesy z nim związane, Studia Miejskie, 14, pp. 13-38.

UE (2011), Cities of tomorrow Challenges, visions, ways forward, European Commission, Directorate General for Regional Policy. Available from http://ec.europa.eu/regional_policy/ sources/docgener/studies/pdf/citiesoftomorrow/citiesoftomorrow_final.pdf [Accessed 12 October 2018].

United Nations (2015a), Transforming Our World: The 2030 Agenda for Sustainable Development, A/RES/70/1. Available from http://www.un.org/ga/search/view_doc.asp?symbol=A/RES/ 70/1\&Lang $=$ E [Accessed 12 October 2018].

United Nations (2015), World Urbanization Prospects: The 2014 Revision, Department of Economic and Social Affairs Population Division (ST/ESA/SER.A/352) Available from https:// esa.un.org/unpd/wup/publications/files/wup2014-report.pdf [Accessed 12 September 2018].

United Nations, 2016, Urbanization and Development: Emerging Futures, World Cities Report 2016. Available from http://wcr.unhabitat.org/wp-content/uploads/2017/02/WCR-2016Full-Report.pdf [Accessed 12 October 2018).

WCDE (1987), Report of the World Commission on Environment and Development: Our Common Future. Available from http://www.un-documents.net/our-common-future.pdf [Accessed 12 October 2018].

Zawieska, J. (2018), Perspektywy implementacji Mobility-as-a-Service w polskich aglomeracjach. In: Mobilność w aglomeracjach przyszłości, Gajewski, J., Paprocki, W., Pieriegud, J. (Eds.), Centrum Myśli Strategicznych, Sopot, pp. 30-48.

\section{Corresponding author}

Barbara Pawłowska can be contacted at: bpawlowska@ug.edu.pl 